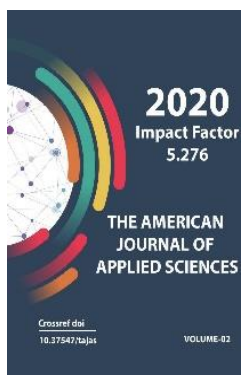

Copyright: Original content from this work may be used under the terms of the creative commons attributes 4.0 licence.

\section{Building Materials Determined In The Architectural Monuments Of Central Asia}

\author{
Xaydarov Abduxalil Mutalib ogli \\ Assistant, The Department Of Construction Of Buildings And Structures, Ferghana \\ Polytechnic Institute, Ferghana, Uzbekistan
}

Teshabayeva Nodira Djurayevna

Senior Lecturer, Department of Construction of Buildings and Structures, Fergana Polytechnic Institute, Fergana, Uzbekistan

\title{
ABSTRACT
}

In the article, the durability of building materials under certain natural and climatic conditions remains one of the most unsolved problems. Each location is different and it is said that the surrounding materials are checked simultaneously and regularly under the influence of a number of factors.

\section{KEYWORDS}

Building materials, standards, laboratory conditions, natural and climatic conditions.

\section{INTRODUCTION}

The durability of building materials in certain climatic conditions remains one of the least resolved problems. Each location is different and the surrounding materials are checked simultaneously and regularly under the influence of a number of factors.

All impacts on materials during their appearance, normal functioning and obsolescence are taken into account in two ways: in the laboratory or by observing materials in nature in long-lived structures, that is, in architectural monuments. Knowing the composition and characteristics of materials, as well as the full range of influences to which they will be exposed over a long period of time, it can be assumed how long each material will last, which, in turn, makes it possible to predict the durability of similar modern materials.

In the difficult and vivid natural and climatic conditions of Central Asia, building materials are tested in various ways for many factors that in one way or another affect their durability. During the year (up to 60-700C) and during the day (up to 250 C), there are sharp fluctuations in air temperature, frequent 
transitions from zero, summer temperatures that greatly heat the surface of buildings (up to $\mathrm{K} 700 \mathrm{C}$ ), dry air, sand and these include strong winds at high speeds, which cause moisture, strong and almost complete soil salinization, and the fact that most of the areas are in the seismic zone.

The long-term durability of the building materials stored in the country's monuments is an object of constant work. A set of external influences on materials is determined, their ability to withstand such influences is determined and the reasons for the greater or lesser resistance of materials are explained. The main role in the study is the observation of materials in architectural monuments in kind with subsequent study of selected samples in the laboratory. First of all, it is necessary to determine from which components the material is made, in what proportions and how.

Due to the lack of written sources, it is generally extremely difficult to restore the original composition of a wide range of building materials. The range of materials, various parts of the structure, the state of their individual types is restored, samples are taken for analysis in the laboratory. At the same time, information is collected about deposits, raw materials that can be used. In the laboratory, samples of materials are studied in detail: their strength, frost resistance, water resistance and other properties are determined, i.e. the physical and technical parameters are determined.

Chemical and spectrographic analyzes were carried out, their structure and mineral composition were studied. The content is calculated based on the analysis results. Based on the obtained content calculations, analogies of the samples are created and the concentration is checked. A comparative study of old and new materials allows you to determine what changes have occurred over a long time of their use.
Based on the composition and characteristics of ancient materials, knowing what effects they affected during operation, it is possible to draw conclusions about the durability of these materials, which, in turn, makes it possible to predict the durability of modern materials like them. It turned out that the studied materials of architectural monuments of Central Asia include: Raw materials - cotton in the form of blocks and shelves; raw bricks of various sizes, fired from clay; clean and mixed with straw, sand and gravel.

The raw material is one of the oldest building materials in Central Asia and has been used regularly for almost 2000 years. Their storage largely depends on the humidity of the environment. The waterproofing and foundation structure of a building converted from raw materials is of great importance. The lower part of clay bases suffers greatly from its capillary rise as the water evaporates.

1. Burned brick is a brick-rectangular, square shape used for lifting columns, filling the upper parts of door frames and windows, making floors, collecting waterproof supports. Since the late ninth century, clay has been commonly used as a cladding material and as a building material in the construction of large structures.

2. Square bricks are widespread almost everywhere. Rectangular bricks are typical for the construction of the cities of Osh, Uzgen, Samarkand and Tashkent in the XI-XII centuries. The strength of the brick when added is $100-200 \mathrm{~kg} / \mathrm{m} 2$, and its frost resistance is characterized by $15-$ 25 freeze-thaw cycles. Regardless of the climatic zone, the storage is very high. The durability of a fired brick directly depends on the degree of its firing: a well-fired brick will quickly collapse under the influence of cold, flood, moisture and wind. Conventional fired brick has good salt resistance compared to well fired 
brick, but moisture will be a capillary absorption zone. Therefore, if it is not protected, it will collapse. Well-fired bricks can be stored anywhere. the brick wall begins to collapse as a result of wet freezing accumulated by splashing wind, rain and snow.

3. Among the unglazed ceramic tiles in ancient buildings, the following can be distinguished:

1. Plated by a brick the size of a polished dial. The covering is smooth, without patterns, and the only decoration is the kungurador, which forms a different arrangement of bricks, the kungurador carpet (the tomb of the Samanids, built in the 10th century in Bukhara) along the relief.

2. Kungrador tiles are made by grinding fired bricks.

3. Smooth tiles used for coverings used in combination with glazed bricks.

4. Bricks with deep relief before firing. The relief creates a prefabricated exterior finish.

5. Slabs, usually called terracotta, are carved in ornaments of varying depth and fineness. With the exception of embossed terracotta, unglazed facing materials usually do not differ from brick, which is collected in terms of preservation and physical and mechanical properties.

As with all unglazed stoneware, shredded terracotta material is healthy soil. If cooked well, the strength of the product will increase and it will reach $600-800 \mathrm{~kg} / \mathrm{m}$. Frost resistance is 50 times higher than other paints and varnishes and can withstand wind and salt corrosion.

\section{Glazed ceramic tiles look like this:}

1. Different facing boards, which differ from the embroidered terracotta only by the glazing of the surface: one color and two different colors.
Preparation and firing of the molded mass, as a rule, as for unglazed terracotta, firing usually has a strength of $180-300 \mathrm{~kg} / \mathrm{m}$. allowed to obtain high quality ceramics.

2. Glazed tiles - wall and tomb. Tiles of the same color have a trapezoidal cross-section and a rectangular face. The size varies depending on the place of use (Bibikhanim-550m.). The surface of the back side is decorated with different roughness (longitudinal deep line, grooves on both sides, etc.), so that the tiles integrate well with the reinforcing composition. The strength of the tiles is in the range of $75-200 \mathrm{~kg}$ / m2, withstands 12-20 freezing cycles. The tiles are well preserved. Glazed ceramics (tiles) based on silicate ceramics. Since the XII-XIII centuries, it has been glazed in the decoration of the monuments of Central Asia.

\section{REFERENCES}

1. Opolovnikov A.V. "Restoration of monuments of national treasures", M., Stroyizdat. 1974.

2. Schilling Cantakzino., P. Brandt. "Building restoration". M., Stroyizdat. 1984.

3. Teshaboeva N.D. Consideration of seismic zones in the design of loadbearing structures. FARPI ITJ NTJ. 2019. №1.

4. Teshaboeva ND Improving the structure and properties of concrete in a dry hot climate with a hydrophobic plasticizing additive.

5. Teshaboeva N.D. IMPROVEMENT OF THE STRUCTURE AND PROPERTIES OF CONCRETE UNDER THE CONDITIONS OF DRY HOT CLIMATE HYDROPHOBIC - PLASTIC ADDITIVE. INTERNATIONAL JOURNAL OF RESEARCH CULTURE SOCIETY Monthly, Peer-Reviewed, 
Refereed, Indexed Journal. Accepted on: 20/11/2019

6. Mirzajonovich, Q. G., Ogli, A. U. A., \& Ogli, X. A. M. (2020). Influence Of Hydro Phobizing Additives On Thermophysical Properties And LongTerm Life Of Keramzitobetona In An Aggressive Medium. The American Journal of Engineering and Technology, 2(11), 101-107.

7. Ogli, X. A. M., Ogli, A. U. A., \& Mirzajonovich, Q. G. (2020). Ways of Implementation of Environmental Emergency Situations In Engineering Preparation Works In Cities. The American Journal of Engineering and Technology, 2(11), 108-112.

8. Mirzaahmedov, A. T. (2020). Accounting For Non-Linear Work of Reinforced Concrete In The Algorithms Of Calculation And Design Of Structures. The American Journal of Engineering and Technology, 2(11), 5466

9. Ogli, A. U. A., Ogli, X. A. M., \& Mirzajonovich, Q. G. (2020). Hazrati Imam Architecture The Complex Is A Holiday Of Our People. The American Journal of Engineering and Technology, 2(11), 46-49 